The Chittagong Univ. J. B. Sci., Vol. 4(1 \&2):13-23, 2009.

\title{
EFFECT OF CHROMIUM, CADMIUM AND MERCURY ON THE GILL HISTOLOGY OF CLARIAS BATRACHUS L.
}

\author{
SHAWKAT ARA BEGUM ${ }^{1}$, QAMAR BANU AND BAHARUL HOQUE \\ Department of Zoology, University of Chittagong, Chittagong-4331, Bangladesh
}

\begin{abstract}
Effect of cadmium $(\mathrm{Cd})$, chromium $(\mathrm{Cr})$ and mercury $(\mathrm{Hg})$ on the gill histology of Clarias batrachus L. was investigated following 28 days exposure to their sublethal concentrations under laboratory condition. Hyperplasia and hypertrophy of the lamellar epithelium, necrosis, partial lifting of epithelial layer, damage of gill ray, oedema of primary lamellae, damage of pillar cells and congestion of blood vessels were the main histopathological changes. In $\mathrm{Cd}$ treated fishes the interlamellar spaces were abolished but distended gill rays were characteristics of $\mathrm{Cr}$ treatment. Extensive cellular and tissue damages were prominent in $\mathrm{Hg}$ treated fishes.
\end{abstract}

Key Words: Heavy metal, Gill histology, Hyperplasia, Hypertrophy, Oedema.

\section{INTRODUCTION}

Heavy metals have been detected in abundance in many waterbodies of Bangladesh (Anonymous 1998, Quraishi and Akhter 2005). In the present work, effect of heavy metals $\mathrm{Cd}, \mathrm{Cr}$, and $\mathrm{Hg}$ on histology of the gill of Clarias batrachus L. was investegated following its exposure to sublethal concentrations for 28 days under laboratory condition.

\section{MATERIALS AND METHODS}

Fresh and live specimens of Clarias batrachus L. (average length $16 \pm 3$ $\mathrm{cm}$ and weight $70 \pm 5 \mathrm{~g}$ ) was bought from Chittagong city market and acclimatized for 7 days in $25 \mathrm{~L}$ aquarium in tap water. Fish species were given oligochaetes, prawn and small pieces of Harpodon nehereus as food once in a day and water was changed at $24 \mathrm{~h}$ interval. Following it, test fish specimens (20 / aquarium) were exposed to sub-lethal concentration of each heavy metal $(\mathrm{Cd}-9$ ppm, $\mathrm{Cr}-12 \mathrm{ppm}$ and $\mathrm{Hg}-0.3 \mathrm{ppm}$ ) separately (treatment) for 28 days along with a control without heavy metal and fed once a day with a change of solution after each feeding.

Corresponding author : 
Method of Humason (1961) was followed for histopathological study. At the end of the exposure period gills from the metal exposed as well as control fishes were isolated, cleaned with physiological saline solution, cut into pieces and fixed in freshly prepared Bouin's fixative. After 24 hours tissues were transferred to $70 \%$ alcohol for preservation. For histological slides preparation tissues were dehydrated in graded alcohol, cleared in benzene and embedded in paraffin. Thin

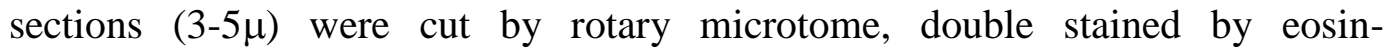
haematoxylin, mounted with DPX for examination under microscope. Photomicrographs were taken by Ricoh $35 \mathrm{~mm}$ SLR camera.

\section{RESULTS AND DISCUSSION}

The gills are among the most delicate structures and owing to their external location and direct contact with surrounding water they are liable to more damage by any irritant materials, whether dissolved or suspended, in the water (Roberts 1989, Watson and Benson 1987). In the present work, some common degenerative changes in gill tissue were developed on exposure to all three heavy metals such as hyperplasia of the gill epithelia, degenerated epithelial cells with pyknotic nuclei, necrosis in epithelium, blood congestion, pillar cell degeneration, mucous exudation, separation of lamellar epithelium, etc. But there were also some metal dependent degenerative changes. Mallat (1985) and Heath (1995) also observed cell degeneration and even total damage of cells of gill epithelia by necrosis on exposure to pollutants.

In the present study extensive proliferation or hyperplasia on the gill tissue of $C$. batrachus was noticed under $\mathrm{Cd}$ treatment that led complete loss of interlamellar spaces between the adjacent secondary lamellae of the entire primary lamella and turned the epithelium a solid mass of cells (Plate 3). The cells of the entire respiratory epithelium were also hypertrophied (swollen) with pyknotic nuclei and clear cytoplasm. Necrotic spots were found at several places of the epithelium. The pillar cell system also showed hyperplasia, hypertrophy and necrosis (Plate 3). The primary lamellae at the base near its origin from the gill arch were degenerated and there were blood clots and mucous cell exudation at some places (Plate 4). Gill rays showed degeneration, necrosis and hyperemic blood vessels. Separation of the lamellar epithelium from the basement membrane was noted in some places of the primary lamellae. Hypertrophy and hyperplasia of the lamellar epithelial cells due to Cd exposure were reported in Zebra fish (Karlsson-Norrgren et al. 1985), in stickleback (Oronsaye 1989), and in the freshwater fish Macropsobrycon uruguayanae (Randi et al. 1996), in Channa 


\section{EFFECT OF CHROMIUM, CADMIUM AND MERCURY ON C. BATRACHUS}

punctatus ( Gupta and Rajbanshi 1988). Similar structural changes in the gill epithelium of different fish species due to other metal and non-metal toxicants have also been reported, e.g., gold fish (Nelson et al. 1999) and Prochilodus scrofa (Mazon et al. 2002) on exposure to $\mathrm{Cu}$, and Liza parsia (Pandey et al. 1997) to $\mathrm{Pb}$.

In course of present investigation the gill rays were extensively distended throughout their lengths (Plate 5) on exposure to $\mathrm{Cr}$, and noted oedema at the tips of the primary lamellae (Plate 6). The oedematous separation of gill epithelium from the basement membrane could be due to the increased capillary permeability and/or lowered efficiency of the epithelial cells in maintaining normal water balance (Roberts 1989). At some places of the gill rays tumour like growth with blood clots were visible (Plate 7). The epithelial cells of the primary and secondary lamellae were hypertrophied and hyperplastic. The hypertrophied gill rays were so expanded that the interlamellar spaces increased greatly making the secondary lamellae distinct. The lamellar epithelium got separated in many places from the basal membrane (Plate 5). Blood cell congestion was found in many places of the respiratory epithelium and in the gill ray. Hyperplastic and hypertrophied tissues around the blood vessels were found in the gill arch at the base of the primary lamellae (Plate 8).

Mercury treated gills of $C$. batrachus showed extensive damage in the epithelium of primary and secondary lamellae. The epithelial and mucous cells were highly damaged, became vacuolated, leaving in some places only the pyknotic nuclei. Lamellar epithelium was necrotic at places and the pillar cells were also degenerated with pyknotic nuclei (plates 9, 10). The entire gill lamellae were atrophied. In the present investigation the gill rays were degenerated and shrunken, and blood sinuses in them were also degenerated. Damage of blood vessels and adjacent tissues at the base of the primary lamellae was evident (plate 9). Similar observations were recorded by Khangarot and Somany (1980) and Galat et al.(1985) while studying the effect of $\mathrm{Hg}$ exposure to Puntius saphore and trout respectively. Pandey et al. (1996) also observed hypertrophy at initial exposure to $\mathrm{Hg}$ at sublethal concentration $(0.02 \mathrm{ppm})$ in Liza parsia, fusion of the secondary gill lamellae on day 8 and extensive cellular hyperplasia (complete filling of interlamellar spaces) after prolonged exposure (15 days). The above mentioned works are in conformity with the findings of the present study. However, Skidmore and Tovel (1972) and Roberts (1989) considered hyperplasia as an adaptive mechanism of the fishes for protection of the underlying tissues from irritant. 
In the present observation mucous exudation was the general pathological symptom noted in the gills of $\mathrm{Cd}, \mathrm{Cr}$ and $\mathrm{Hg}$ treated fishes. The mucous secretion along with proliferated primary lamellar epidermis could have form a respiratory exchange obstruction on its own (Roberts 1989). Damage of the pillar cell system, congestion of blood and necrosis in the lamellar epithelium were common in the cases of all three heavy metals which corroborated with that of others (KarlssonNorrgren et al. 1985, Pandey 1994, Pandey et al. 1996). It may be inferred that this kind of lesion might affect the gill by reducing the supply of blood and might cause respiratory impairment.

\section{REFERENCES}

ANONYMOUS. 1998. Industrialization and industrial pollution. In: Bangladesh Environment: Facing the 21st century. (Ed., Gain, P.). SEHD., Dhaka pp.165-185.

GALAT, D. L., POST, G., KEEFE, T. J. AND BOUCK, G. R. 1985. Histological changes in the gill, kidney and liver of Lahontan cutthroat trout, Salmo charki henshawi, living in lakes of different salinity-alkalinity. J.Fish Biol. 27:533-552.

GUPTA, A. K. AND RAJBANSHI, V. K. 1988. Acute toxicity to cadm ium to Chanua punctatus (Bloch). Acta hydrochim. hydrobiol. 16(5): 525-535.

HEATH, A. G. 1995. Water Pollution and Fish Physiology. CRC Press, Boca Raton, Florida.

HUMASON, L. G.1961. Animal tissue technique. $2^{\text {nd }}$ ed. W. H. Freeman and Company. Sunfrancisco, U.S.A.

KARLSSON-NORRGGREN, L., RUNN, R., HAUX, C. AND FORLIN, L. 1985. Cadmium induced changes in gill morphology of zebra fish, Brachydanio rerio (Hamilton-Buchanon), and rainbow trout, Salmo gairdneri Richardson. J. Fish. Biol. 27(1): 81-95.

KHANGAROT, B. S. AND SOMANI, R. C. 1980. Toxic effects of mercury on the gills of a fresh water teleost, Puntius sophore(Ham.). Curr. Sci. 49:832-834.

MALLAT, J. 1985. Fish gill structural changes induced by toxicants and other irritants: a statistical review. Canadian J. Fish. Aquat. Sci. 42(4): 630648.

MAZON, A. F., CERQUEIRA, C. C. C. AND FERNANDES, M. N. 2002. Gill cellular changes induced by copper exposure in the South American tropical freshwater fish Prochilodus scrofa, Environ. Res. Sec. A 88: $52-63$. 
NELSON, K., JONES, J., JACOBSON, S. AND REIMSCHUESSEL, R. 1999. Elevated blood urea nitrogen (BUN) levels in gold fish as an indicator of gill dysfunction. J. Aquat. Animal Health 11(1): 52-60.

ORONSAYE, J. A. O. 1989. Histological changes in the kidneys and gills of the stickleback, Gasterosteus aculeatus L. exposed to dissolved cadmium in hard water. Ecotoxicol. Environ. Safety 17(3): 279-290.

PANDEY, A. K. 1994. Branchial and renal lesions in the estuarine mullet, Liza parsia, exposed to sub-lethal concentration of mercury. Proc. Nat. Acad. Sci., India 64(3) III: 283-287.

PANDEY, A.K., GEORGE, K.C. AND PEER MOMAMED, M. 1996. Histopathological alterations in the gill of a teleost, Liza parsia, induced by mercuric chloride. Indian J. Fish. 43: 285-291.

PANDEY, A.K., GEORGE, K.C. AND PEER MOMAMED, M. 1997. Histopathological alterations in the gill and kidney of an estuarine mullet, Liza parsia (Hamilton-Buchanon), caused by sub-lethal exposure to lead (Pb). Indian J. Fish. 44(2): 171-180.

QURAISHI, S. B. AND AKHTER, S. 2005. Study of concentration of some toxic and essential elements in marine water, sediment and their impact on marine biota. J. Bangladesh Acad. Sci. 29(2): 163-171.

RANDI, A. S., MONSERRAT, J. M., RODRIGUEZ, E. M. AND ROMANO, L. A. 1996. Histopathological effects of cadmium on the gills of freshwater fish, Macroprobrycon uruguayanae Eigenmamn (Pisces, Atherinidae). J. Fish Diseases 19(4): 311-322.

ROBERTS, R. J. 1989. Fish pathology. $2^{\text {nd }}$ ed. Balliere Tindall. London, $21 \mathrm{pp}$.

SKIDMORE, J. F. AND TOVELL, P.W.A. 1972. Toxic effects of zinc sulphate on the gills of rainbow trout. Water Res. 6: 652-653.

WATSON, C.F. AND BENSON, W.H. 1987. Comparative activity of gill ATPase in three freshwater teleostes exposed to cadmium. Ecotoxicol. Environ. Safety 14(3): 252-259. 
BEGUM ET AL..

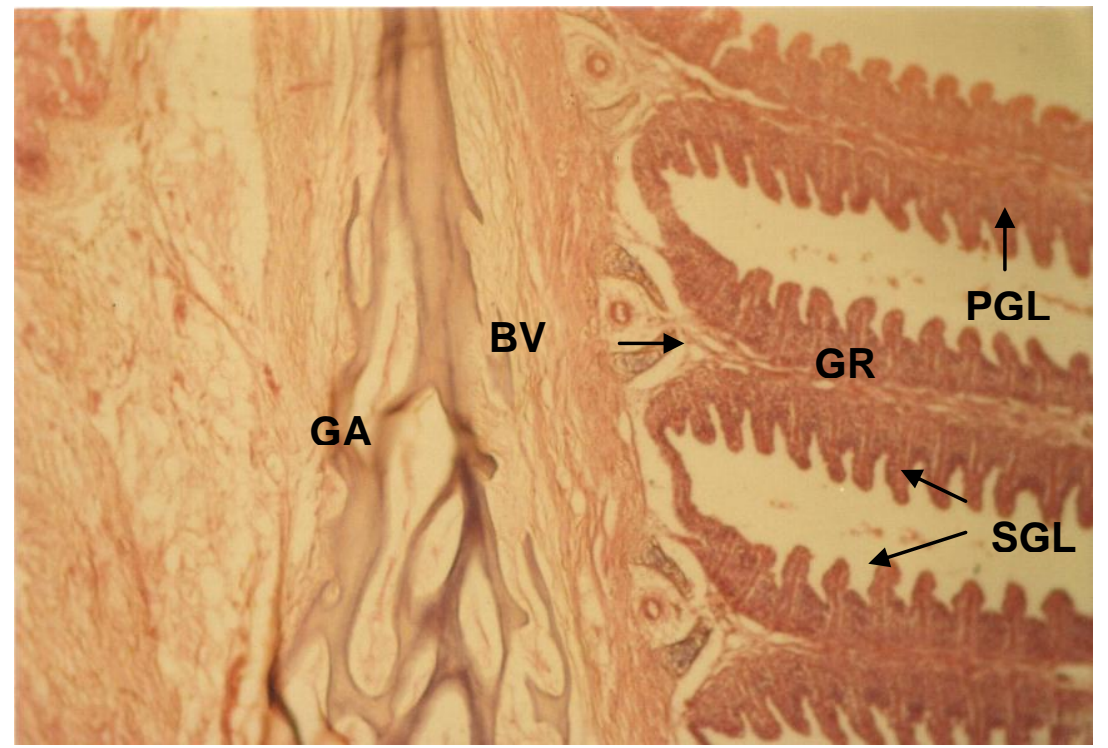

PLATE 1 PHOTOMICROGRAPH OF THE SECTION OF GILL OF CONTROL SPECIMEN OF CLARIAS BATRACHUS SHOWING GILL ARCH (GA), PRIMARY GILL LAMELLA (PGL), SECONDARY GILL LAMELLA (SGL), GILL RAY (GR) AND BLOOD VESSEL (BV). H\&E $10 \times 10$.

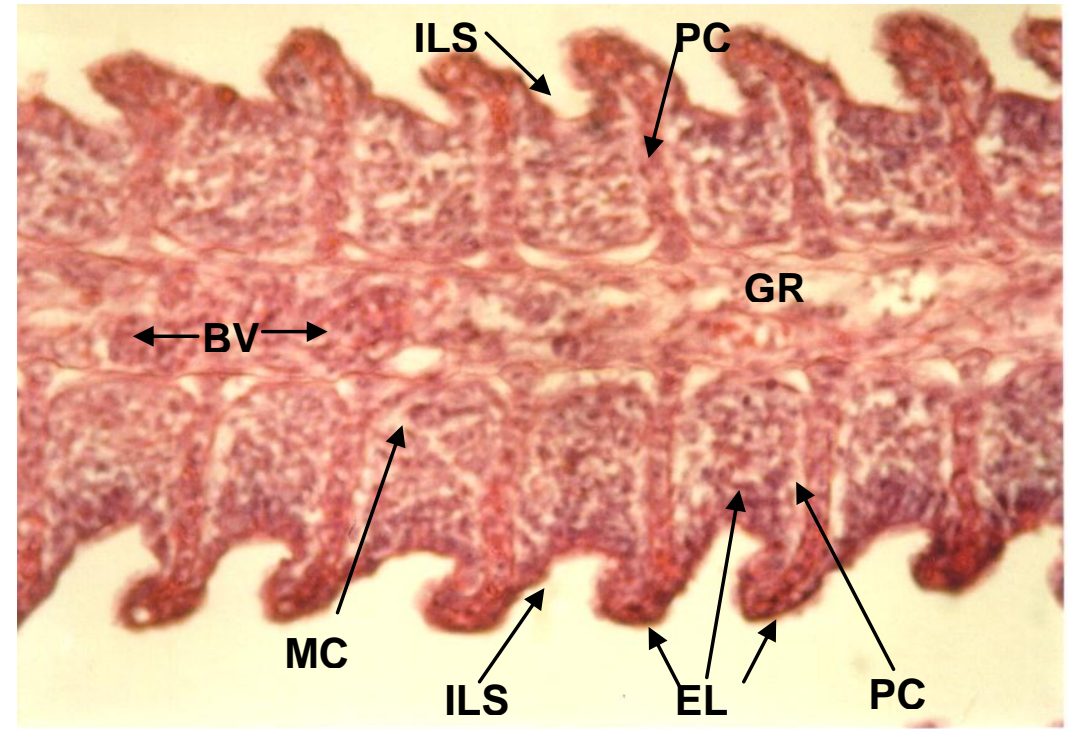

PLATE 2 PHOTOMICROGRAPH OF THE SECTION OF GILL OF CONTROL SPECIMEN OF CLARIAS BATRACHUS SHOWING EPITHELIAL LAYER (EL) OF PRIMARY AND SECONDARY GILL LAMELLAE, MUCOUS CELLS (MC), PILLAR CELLS (PC), AND BLOOD VESSELS (BV) WITHIN THE GILL RAY (GR), AND INTERLAMELLAR SPACES (ILS). H\&E.10×40. 


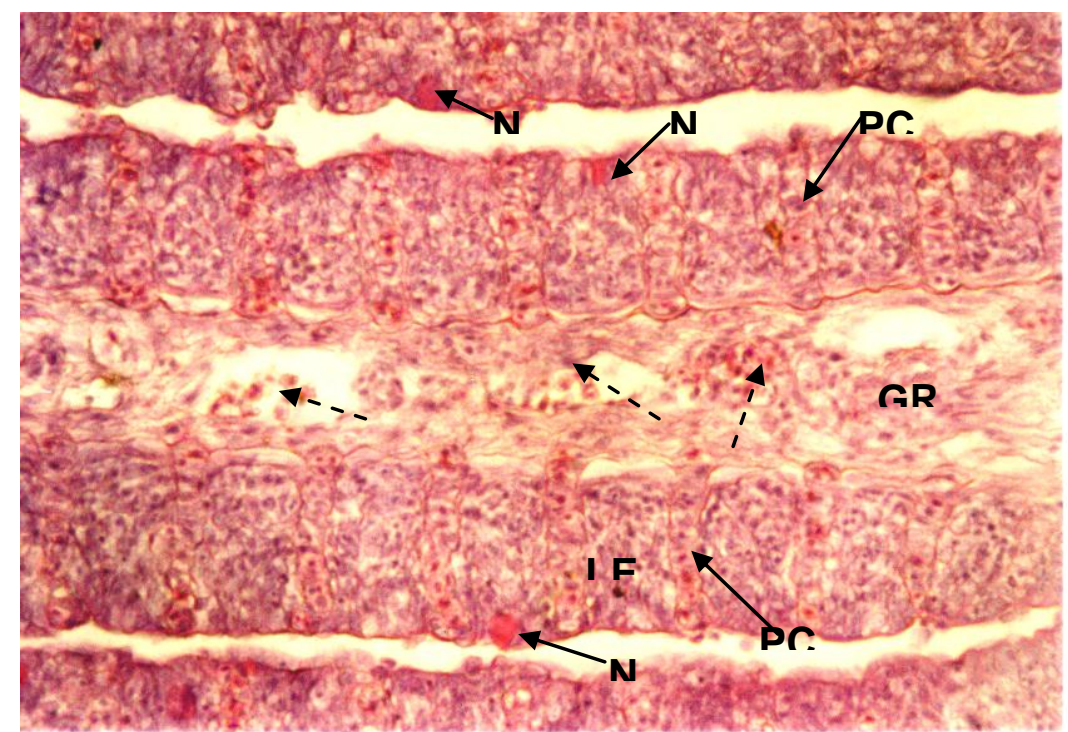

PLATE 3 PHOTOMICROGRAPH OF THE SECTION OF GILL OF CD-EXPOSED CLARIAS BATRACHUS SHOWING HYPERPLASTIC AND HYPERTROPHIED LAMELLAR EPITHELIA (LE) ABOLISHING INTERLAMELLAR SPACES, NECROSIS (N) IN LAMELLAR EPITHELIUM, NECROSED PILLAR CELLS (PC), AND CONGESTION OF BLOOD (BROKEN ARROW) IN GILL RAY (GR). H\&E 10×40.

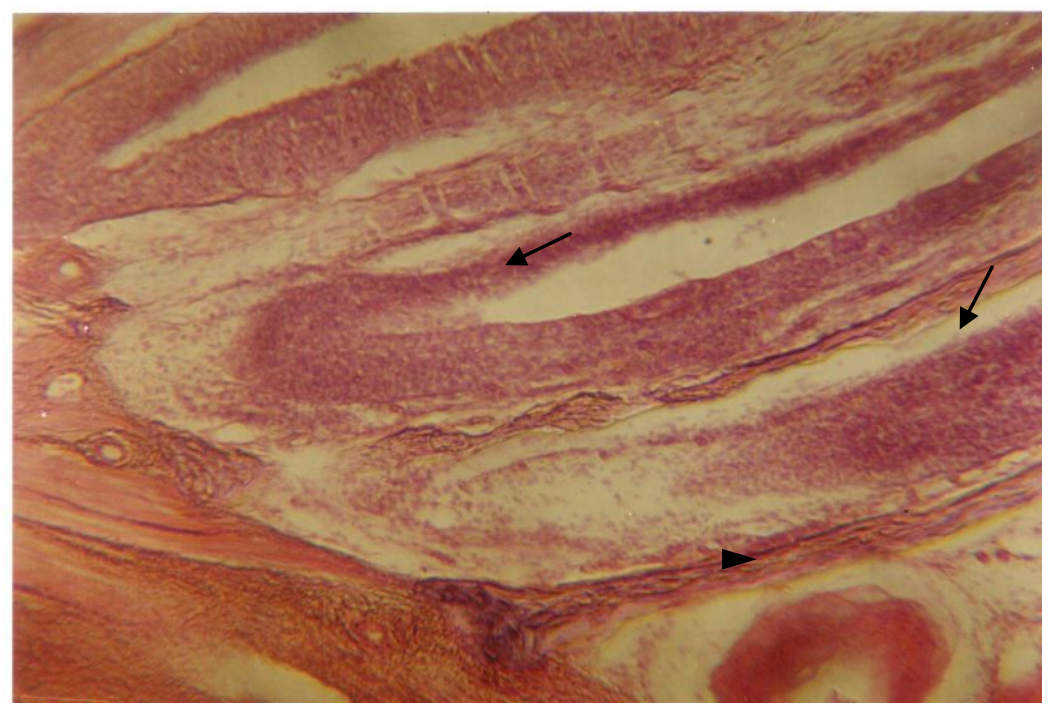

PLATE 4 PHOTOMICROGRAPH OF THE SECTION OF GILL OF CD-EXPOSED CLARIAS BATRACHUS SHOWING MUCOUS CELL EXUDATION AT THE BASE OF THE PRIMARY GILL LAMELLAE (ARROW), AND DILATION OF BLOOD VESSEL (ARROW HEAD). $\mathrm{H} \& \mathrm{E} 10 \times 40$. 
BEGUM ET AL..

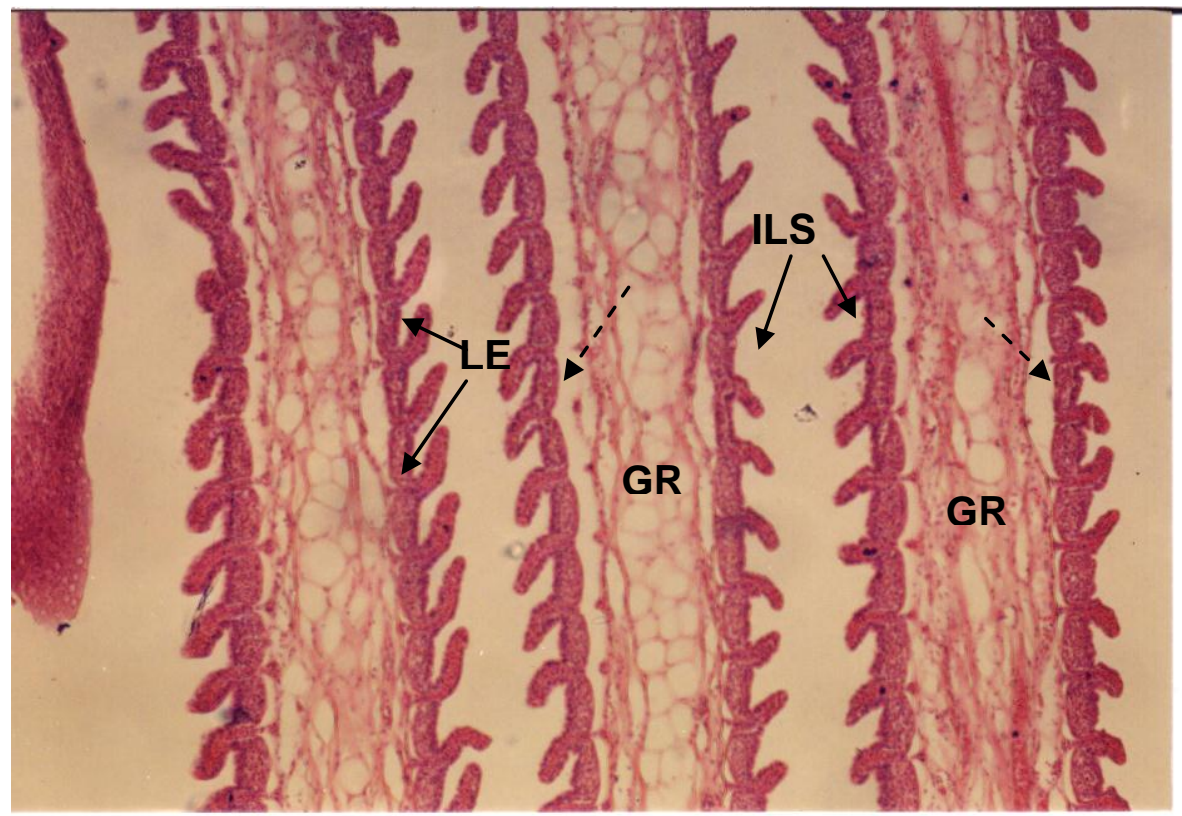

PLATE 5 PHOTOMICROGRAPH OF THE SECTION OF GILL OF CR-EXPOSED CLARIAS BATRACHUS SHOWING DISTENDED GILL RAY (GR), HYPERTROPHIED AND HYPERLASTIC EPITHELIA (LE), WIDE INTERLAMELLAR SPACES (ILS), AND SEPARATION (BROKEN ARROW) OF LAMELLAR EPITHELIUM (LE). H\&E 10×10.

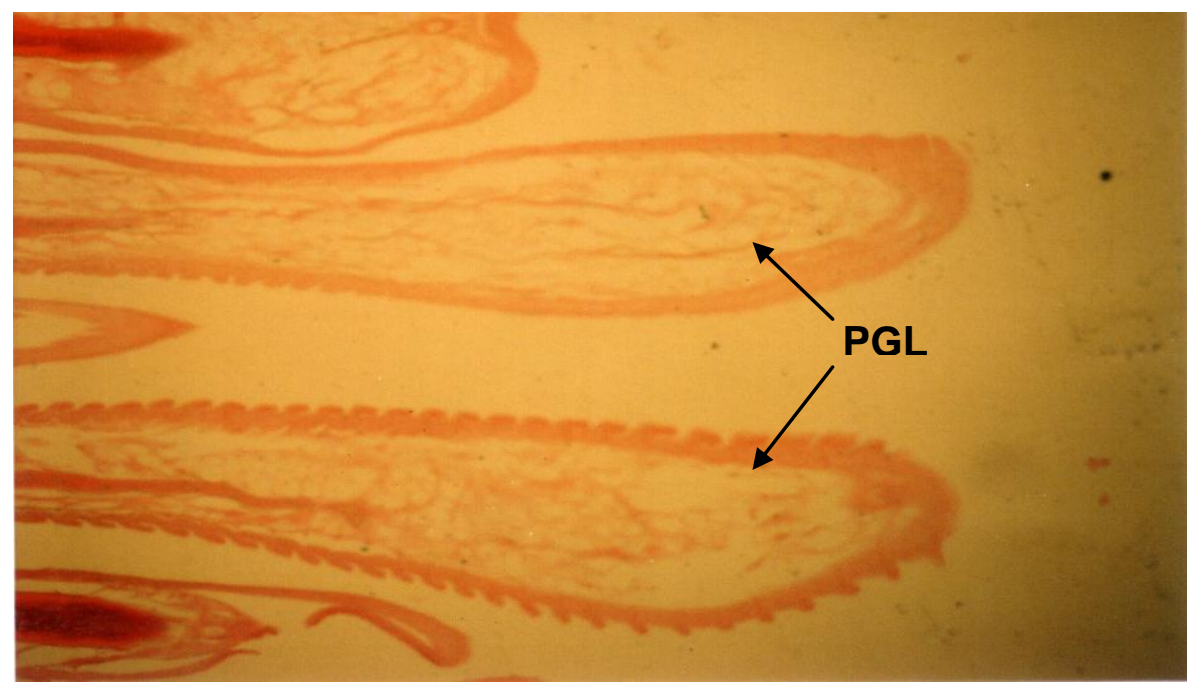

PLATE 6 PHOTOMICROGRAPH OF THE SECTION OF GILL OF CR-EXPOSED CLARIAS BATRACHUS SHOWING OEDEMA AT THE TIPS OF PRIMARY GILL LAMELLAE (PGL) $\mathrm{H} \& \mathrm{E} 10 \times 10$. 


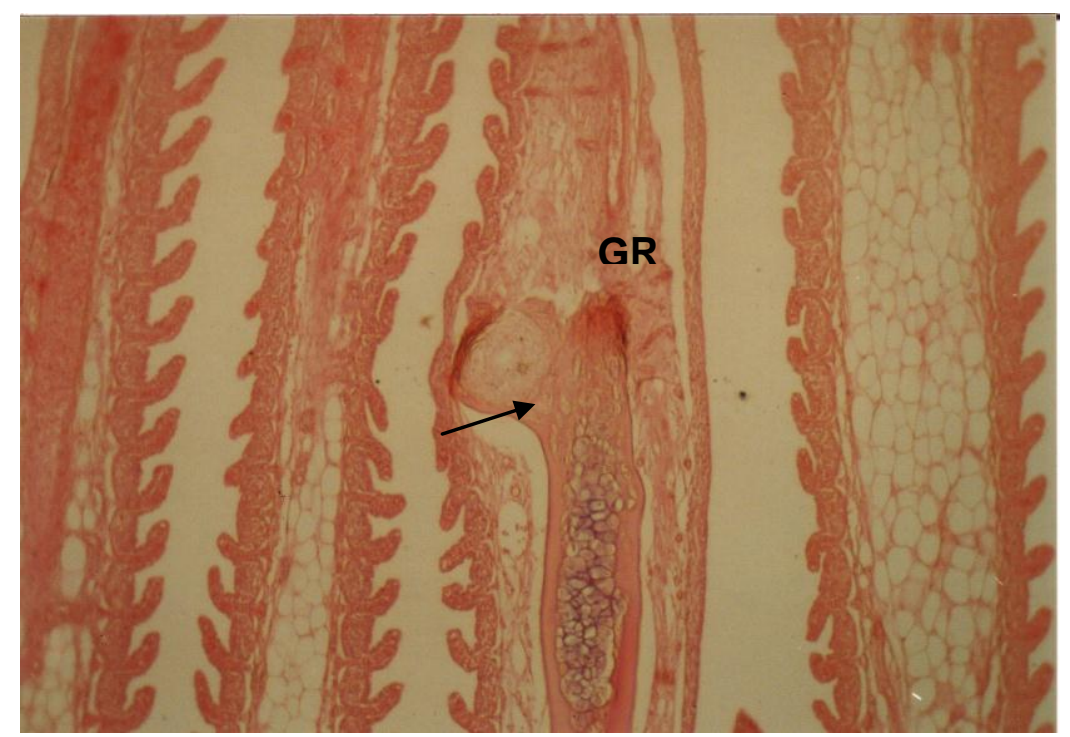

PLATE 7 PHOTOMICROGRAPH OF THE SECTION OF GILL OF CR-EXPOSED CLARIAS BATRACHUS SHOWING TUMOUR LIKE GROWTH (ARROW) IN THE GILL RAY (GR). $\mathrm{H} \& \mathrm{E} 10 \times 10$.

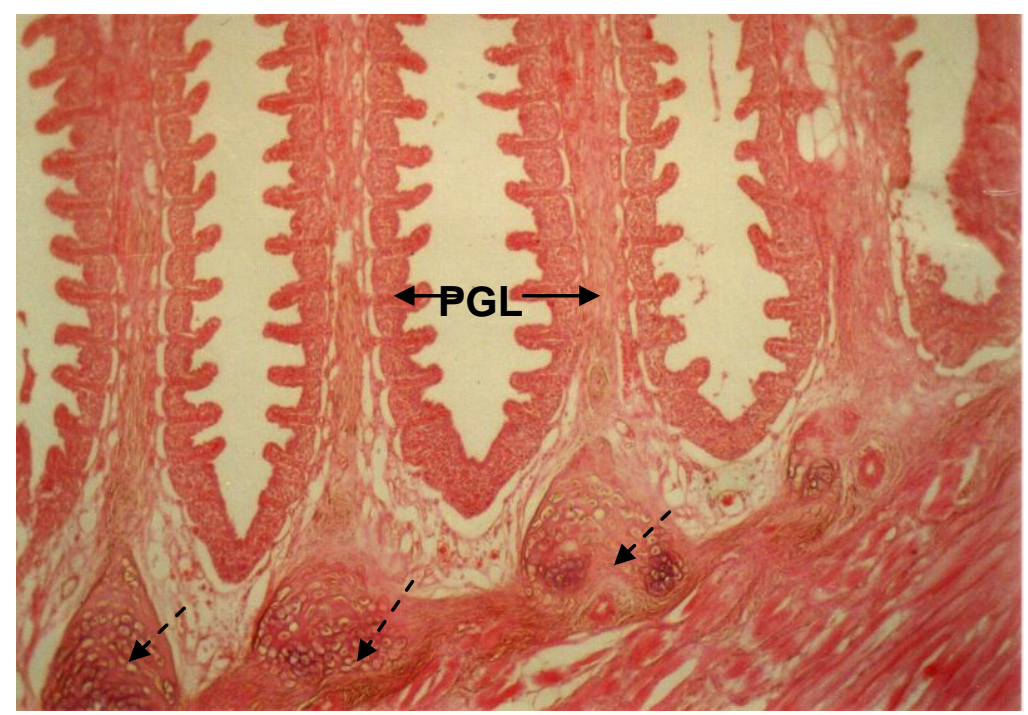

PLATE 8 PHOTOMICROGRAPH OF THE SECTION OF GILL OF CR-EXPOSED CLARIAS BATRACHUS SHOWING HYPERPLASIA AND HYPERTROPHY OF THE TISSUE AROUND THE BLOOD VESSELS IN THE GILL ARCH (BROKEN ARROW) AT THE BASE OF THE PRIMARY GILL LAMELLAE (PGL). H\&E 10×10. 


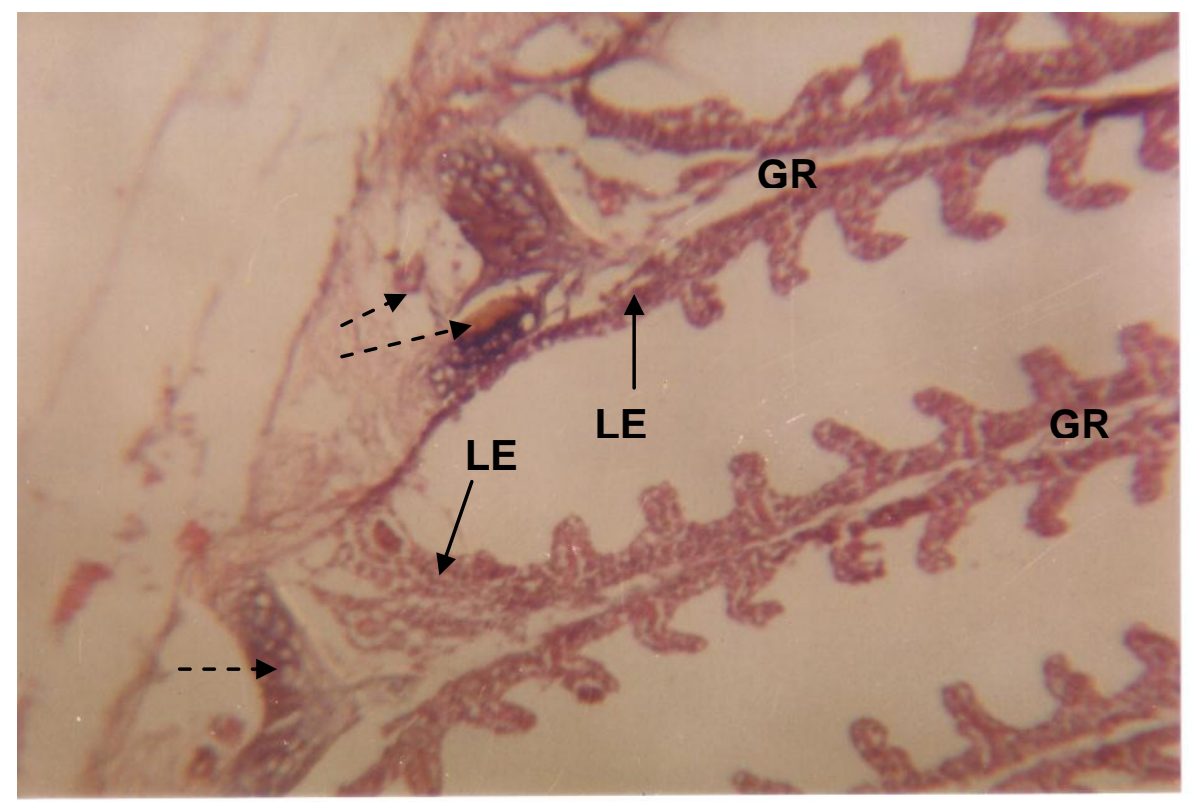

PLATE 9 PHOTOMICROGRAPH OF THE SECTION OF GILL OF HG-EXPOSED CLARIAS BATRACHUS SHOWING HIGHLY DAMAGED LAMELLAR EPITHELIA (LE) DEGENERATION AND SHRINKAGE OF GILL RAY (GR), AND DEGENERATION OF BLOOD VESSELS AND ADJACENT TISSUE IN THE GILL ARCH (BROKEN ARROW). H\&E $10 \times 10$. 


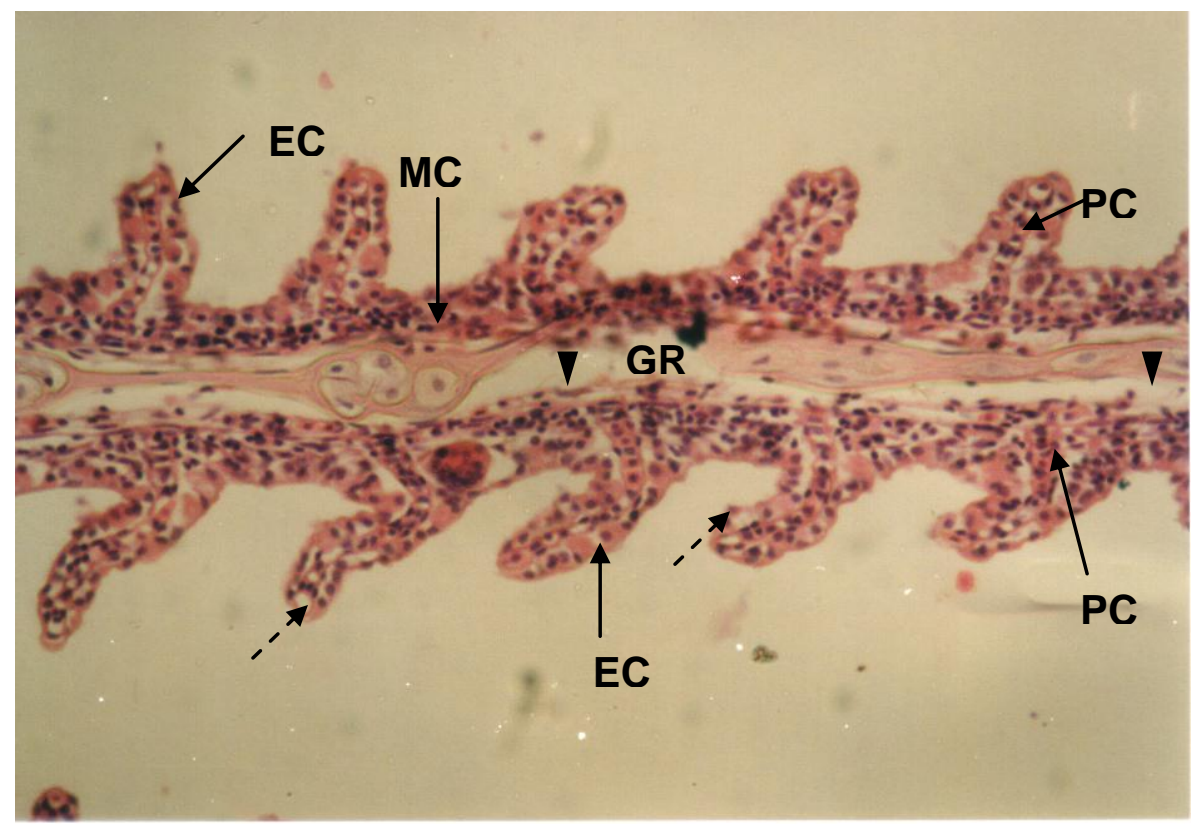

PLATE 10 PHOTOMICROGRAPH OF THE SECTION OF GILL OF HG-EXPOSED CLARIAS BATRACHUS SHOWING HIGHLY DEGENERATED EPITHELIAL CELLS (EC) AND MUCOUS CELLS (MC), VACUOLATION OF CELLS (BROKEN ARROW), PYKNOSIS OF NUCLEI, DEGENERATED AND SHRUNKEN GILL RAY (GR), DEGENERATED PILLAR CELLS (PC) WITH PYKNOTIC NUCLEI; AND SEPARATION OF NECROTIC LAMELLAR EPITHELIUM (ARROW HEAD).H\&E 10×40.

Manuscript received on 10.11.08; Accepted on 4.1. 10

The Chittagong University Journal of Biological Sciences, Vol.4 ( 1 \& 2): Page No : 13-23 